23. Centre for Epidemiology and Research. Summary report on adult health from the NSW Population Health Survey, 2009. Sydney: NSW Department of Health; 2010.

24. Mahajan D, Campbell-Lloyd S, Roomiani I, Menzies R. NSW Annual Adverse Events Following Immunisation Report, 2009. N S W Public Health Bull 2010; 21(9-10): 224-33. doi:10.1071/NB10048

25. World Health Organization. Safety of pandemic A (H1N1) influenza vaccines. Wkly Epidemiol Rec 2010; 85(5): 29-36.

26. Nolan T, McVernon J, Skeljo M, Richmond P, Wadia U, Lambert $\mathrm{S}$ et al. Immunogenicity of a monovalent 2009 influenza A (H1N1) vaccine in infants and children: a randomized trial. JAMA 2010; 303(1): 37-46. doi:10.1001/ jama.2009.1911

27. Australian Government Department of Health and Ageing. Therapeutic Goods Administration, Cook J. Australian experience with non-adjuvant H1N1 vaccine (Panvax and Panvax Junior). Medicines Safety Update No. 4, 2010. Available from: http://www.tga.gov.au/adr/msu/msu1008.htm\#austexper (Cited 30 August 2010.)

28. Australian Government Department of Health and Ageing, Therapeutic Goods Administration. Australian Technical Advisory Group on Immunisation (ATAGI) and Therapeutic Goods Administration (TGA) Joint Working Group Analysis of febrile convulsions following immunisation in children following monovalent pandemic H1N1 vaccine (Panvax/Panvax Junior, CSL). Available from: http://www.tga.gov.au/safety/alerts-medicine-seasonalflu-100928.htm (Cited 30 May 2011.)

29. Australian Government Department of Health and Ageing, Therapeutic Goods Administration. Suspected adverse reactions to Panvax ${ }^{\circledR}$ reported to the TGA. 30 September 2009 to 17 September 2010. Available from: http://www.tga.gov.au/safety/ alerts-medicine-panvax-091120.htm (Cited 30 May 2011.)

30. Australian Government Department of Health and Ageing, Therapeutic Goods Administration. Investigation into febrile reactions in young children following 2010 seasonal trivalent influenza vaccination. Status report as at 2 July 2010 (updated 24 September 2010). Available from: http://www.tga.gov.au/ safety/alerts-medicine-seasonal-flu-100702.htm (Cited 30 May 2011.)

31. Australian Government Department of Health and Ageing, Therapeutic Goods Administration. Departmental Media Releases 23 April 2010. Seasonal Flu Vaccine and young children. Available from: http://www.health.gov.au/internet/ main/publishing.nsf/Content/mr-yr10-dept-dept230410.htm (Cited 30 May 2011.)

32. Australian Government Department of Health and Ageing, Therapeutic Goods Administration. Departmental Media Releases 30 July 2010. Seasonal flu vaccination for young children can be resumed-Updated advice from the Chief Medical Officer. Available from: http://www.health.gov.au/ internet/main/publishing.nsf/Content/mr-yr10-deptdept300710.htm (Cited 30 May 2011.)

\title{
New Senior Hospitalist Initiative: a new medical career pathway for NSW Health
}

New South Wales (NSW) is developing a new medical career pathway for hospitalists. Hospitalists will provide a range of clinical services and promote coordinated patient care across disciplines. The establishment of the hospitalist role and development of an education program for experienced non-specialist doctors was recommended by the Garling Special Commission of Inquiry into Acute Care Services in NSW public hospitals. The report recognised that "Hospitalists have an important role in coordinating the care of a patient who has needs which cross boundaries of individual specialities".

The hospitalist pathway offers a flexible, interesting and attractive career to non-specialists keen to remain involved in acute patient care, while leading improvements in the coordination of hospital services. The pathway will be supported by the Masters of Clinical Medicine (Leadership and Management) which will focus on the range of skills required for senior hospitalist roles within NSW Health. The Masters, or equivalent, will be a requirement for eligibility for NSW Health Senior Hospitalist positions as an alternative to the Senior Career Medical Officer Grading Committee.

The 2-year part-time Masters, endorsed by NSW Health, will begin in 2012. The program is open to non-specialist doctors with 3 years full-time postgraduate medical experience. It will be accessible statewide through flexible delivery options and will have a substantial workplace component. To support eligible NSW Health doctors to participate in the Masters, the Department will sponsor 15 places in 2012.

Those interested in finding out more about the Senior Hospitalist Initiative, including sponsorship and enrolment information, should check the NSW Health website at: http://www.health.nsw.gov.au/training/hospitalist/

Cathie Hull, Senior Policy Officer, NSW Ministry of Health

Catherine Ellis, Principal Policy Analyst, NSW Ministry of Health 